\title{
"Gratification" in Press Events through the Public Relations Practitioners and Journalists's Perspective
}

\author{
Novita Damayanti ${ }^{1}$, Prasetya Yoga Santoso ${ }^{2}$ \\ \{novita.damayanti@dsn.moestopo.ac.id ${ }^{1}$,prasetyayoga@dsn.moestopo.ac.id ${ }^{2}$ \} \\ ${ }^{1,2}$ Faculty of Communication Science, University Prof. Dr. Moestopo, Jakarta, Indonesia Jl. \\ Hang Lekir I/8 Gelora, Jakarta Pusat, Indonesia 10270.
}

\begin{abstract}
This research focuses on the relationship of media relations which has various objectives to establish good relations with the media. The organizations get advantage from good publicity. In media relations, there are several press events such as press conferences, press visits, gathering press, interviews, and others. There were still some practices of giving envelopes or tipping to journalists in several press events by the organization. Furthermore, this practice breaks the rules of the code of ethics from the perspective of journalist's professional ethics and Public Relation. It is related to the journalistic code of ethics that Indonesian journalists can not taking advantage from the profession and accepting bribes. Bribery is gifts such as money, objects or facilities from other parties that affect the journalist's independence. This study aims to find out the perspectives of PR practitioners and the journalists. Ethically, giving "envelopes" or tipping is prohibited. The journalist's code of ethics also prohibits the journalists to receive any envelopes or tipping while carrying out their duties. The scope of problem is limited to Jakarta region. The study is conducted to comprehend how gratification in media relation is comprehended through PR and journalist's perspective. This study uses a qualitative approach in case study method. Data were collected from interview and Focus Group Discuss (FGD) with several PR consultants, PR corporate, and PR government. Meanwhile, several journalists from the media will be invited to describe their point of views due to this matter.
\end{abstract}

Keywords: Media relations, public relations, journalist, code of ethics, press events

\section{Introduction}

Public Relations (PR) activities in the media, especially journalists, constitute a large portion of public relations duty in various organizations such as private, government and nonprofit. This relationship is media relations which has various objectives to establish good relations with the media. It is related to the organization good image in publications. There are several press events in media relations such as press conferences, press visits, press gatherings, interviews and others. There were still some practices of giving envelopes to journalists in several press events where the organization invited journalists. It interrupts upon the code of ethic due to the point of view of professional ethics of journalists and PR. It is related to the law about press number 6 in Ethics of Journalism. Indonesia did not taking advantage of the profession and bribes. In the explanation of the article, bribery is gifts such as money, objects or facilities from other parties that affect independence. The IPRA code of ethics [2] which was adopted in 2011 is an affirmation of professional ethics from members of 
the International Public Relations Association. It is recommended to practitioners of public relations throughout the world. This code of ethics is an improvement from Code of Venice in 1961, Code of Athens in 1965 and Code of Brussels in 2007.

Journalists are partners and companion for public relations in publishing information due to wider audience. Ethically, "envelopes" or "jale" must be avoided by PR and journalists. Apart from their respective professional ethics, the practice of giving and receiving envelopes during press events still occurs especially in Jakarta. The gray area has many considerations in ethics, culture and habits of a country. It makes this problem worthy to investigate. It becomes the foundation for journalists on duties. There is an assumption that the profession of journalist is still low in income and this is one of the considerations. Furthermore, the proliferation of mass media nowadays makes competition between the media itself to get publications for both mass media and non-media.

The limit of gratification at press events have not been clear and are still ambiguous. Gratuity is related to the money (envelope) or the gifts (goods). Each media and company has rules and judgments that give limitations to both media such as journalists and PR. Limitation of this problem is in Jakarta. This study wants to understand PR's and journalists perspectives about gratuities in media relations. This study aims to determine the perspectives of public relations practitioners and journalist on giving envelopes (Jale) on press events.

\section{Public Relations and Media Relations}

Public Relation is stated by Howard Bonham, Vice Chairman, American National Red Cross: "Public Relations is the art of bringing about better public understanding which breeds greater public confidence for any individual or organization. Glenn and Denny Griswold state "Public Relations is the management function which evaluates public attitudes, identifies the policies and procedures of an individual or organization with the public interest and axecutes a program of action to earn public understanding and acceptance". The purpose of professional public relations is to create understanding. Baines et. al. [3] discuss about Public Relations function as a proffesional: ability to get on with people and good personal integrity.

The purpose of professional public relations creates understanding. Jefkins states public relations practice as the art and social science of the analysing trends, predicting their consequences, counselling organization leaders, and implementing planned programs of action that will serve both the organization's and the public interest [3]. The name of press officer may appear since this person has to deal with media as well as press. As for public relations generally the press or media relations officer needs to be both proactive and reactive. Harrison (2000) argues that they must act positively on behalf of the organization. This should include taking the initiative in introducing and maintaining contact with the media rather than simply waiting for the request. PRSSA, Baran [4] defines Media Relations as "... the public relations professional maintain good relations with professionals in the media, undestrand their deadlines and other restraints, and earn their trust".

\subsection{Journalist}

In Law No. 40 of 1999 about Press article 1, journalists regularly conduct journalistic activities. There are three different titles in the same profession such as newsmakers, journalists and reporters. These titles have the same meaning as a profession of search, collect, select and disseminate information to the public through mass media. Journalists carry out journalistic activities. The term journalism is etimologically derived from Latin "Journal or do jour". It is a translation of "Journal means daily" as diary. In its development, journalism is 
used in various languages such as "journalistic" from Dutch and "journalism" from English. Journalism is related to the collection, writing and dissemination of various media through newspapers, magazines, television and radio.

\subsection{Ethics Code of Public Relations and Journalists}

Based on Broom [5], Ethical suggests to the consistent actions of moral norms in society. In professions, the application of moral values in practice is referred to as applied ethics. Most media major have ethics codes that prohibit their journalists from accepting nepotisms. The mission of the public relations is building good relationships with all of the organization's public. It is included both public relations practitioners and journalists to shape public opinion about the obligations of truth and accuracy under the law.

Professional development is a scientific expertise in a particular field. Therefore, they are able to fulfill the community needs independently. The profession concerns to decide about professional development activities. He is personally responsible for the quality of services. Therefore, the nature of the relationship between professional carriers and patients or clients is a personal relationship. It is included the relationship between value-supporting subjects.

Adherence of professionals to the code of ethics is an instinctive obedience that has integrated with the mind, soul, and behavior of professional staff. This research explores professional ethics, factors and effects related to ethics and professional responsibility. Therefore it can be concluded about the professional elites such as strong awareness to professional ethics when they want to provide services of professional expertise to the local communities.

Courtland et . al., [6] argues ethics as the principle of behavior to manage a person or community. Immoral person do whatever to achieve their goals. Nobel people are generally trustworthy, fair and impartial. They also respect others and show anxiety for the influence of actions in society.

\subsection{Public Relations Code of Ethics}

There are four kinds of codes of ethics that must be followed by the first public relations practitioner. The first is code of conduct. It is ethics of everyday behavior towards personal integrity, clients and employers, the media and the public, as well as behavior towards colleagues. Second, it is code of profession. It is ethics in carrying out the duties or professions of the public relations. Third, Code of publication is ethics in the process and technical issues. Fourth, code of enterprise is concerning aspects of government regulations such as licensing and business law, copyright, brands, etc.

Ethic is related to moral in society. It is determined by professional standards, organizations, and individuals. Ethic is the main consideration in distinguishing between citizens who are dealing with and those who are not in society. Allen Center proposes five factors to manage social behavior such as tradition, public opinion, law, morality and ethic. Tradition is comprehended and enforced situation in the past. Public opinion is accepted behavior by the majority of people at that time. Law is permitted behavior by regulation. Morality is permitted behavior by religion. Ethic is determined behavior by professional standards, organizations, and individuals on conscience - what is right and fair for others and for oneself.

Public relation takes a role as an advisor by giving critic to their client's problems. The cliens can be politicians, companies, or celebrities. However, most public relations practitioners' appointments in a case will have a good impact, because they will provide clarity 
and benefit for everyone involved. It includes the mass media. It reflects the ethical of PR practitioner as an ethical. It requires a neutral view of PR.

Baker \& Martinson [7] determine five principles in working place such as truthfulness, authenticity, respect, and social responsibility. For the principle of truth, PR practitioners are in strict control especially by journalists who consider PR practitioners as enemies. Professionally, practitioners of public relations have professional ethics or public relations ethics codes that must be adhered to. Thus, public relations practitioners must have high personal ethical standards that inspire their work as public relation practitioners.

Professionaly, a public relations practitioner is able to understand and apply the code of ethics correctly due to his profession. It has a positive impact on his profession and for himself. In this case, public relations practitioners are required to have abilities such as communicating, organizing, associating, relating, and having strong personality. In addition, they must also have high skills in mastering information technology to support their works. From these abilities and skills, a public relations practitioner is a professional due to his code of ethics.

The PR code of ethics is a reference for every policy. It is taken by public relations practitioners in carrying out their duties responsibly. A professional PR will work with full awareness of the code of ethics. Then, he will work in the best ability and pay attention to all his work based on the code of ethics. The impact of not implementing the PR code of ethics has an effect on the public relations practitioners themselves and the company.

\subsection{Journalist Code of Ethics}

Carrying out the duties and responsibilities of an informant, especially the journalist, is included in the Law No. 40 of 1999 about the press and the journalistic code of ethics. Protection and consent for violations of law by the press or journalists will be legal consents due to the violations. So, the protection of press rights has been guaranteed in Law about the press No. 40 of 1999.

There are a number of ethics or principles in journalism which should be the responsibility of every journalist. Bill Kovach and Tom Rosenstiel [8] formulated these principles in the Nine Elements of Journalism. In its development, nine elements have become ten elements such as; 1) Journalism's first obligation is to the truth; 2) The first loyalty of journalism is to citizens; 3) The essence of journalism is the discipline of verification; 4) Journalists must remain independent of the parties they cover; 5 ) Journalists must serve as independent monitors of power; 6 ) Journalism must provide a forum for criticism and comments from the public; 7 ) Journalism must try to make important things interesting and relevant; 8 ) Journalists must keep the news comprehensive and proportionate ; 9 ) Journalists have an obligation to follow the voice of their conscience; 10 ) Residents also have rights and responsibilities in materials relating to the news .

There are four elements of ten elements of journalism are strongly related to this research. The four elements are: journalism is the truth, the first loyalty of journalism is to citizens, the essence of journalism is the discipline of verification, and journalists must remain independent of the parties they cover. Kovach [8] believes the obligation of journalists to convey the truth. Society can get the information to be sovereign.

The form of "journalistic truth" is not just accuracy but a practical and functional form of truth. This is not absolute or philosophical truth. However, it is a sorting-out process that develops between the initial story and the interaction between the public, news makers, and journalists at certain times. The first principle of journalism -the pursuit of truth, which is not 
based on certain interests (disinterested pursuit of truth)- is what distinguishes it most from other forms of communication

\section{Method}

This research is qualitative research that study object in natural conditions. Researchers try to understand, interpret, and deduce a phenomenon conveyed by respondents to researchers of Denzin \& Lincoln [9] in methodological aspects. This research uses case study research strategies.

According to Yin [10], the case study is an empirical investigation that investigates a real contemporary phenomenon especially limitation between noticeable phenomena and contexts. The informants knew a lot about the actual reality in this study. Determination of informants is based on purposively by considering the ability of informants in giving information related to the nepotism to press evants. This study aims to determine the perspectives of PR practitioners and journalist's side. This research focuses on the observation of PR and journalists regarding envelopes (Jale) at press events. The technique of data collection in this study uses interviews, FGD (Focus group discussion) and documentations.

\section{Results}

PR and journalists are partners in working place. They always need each other. With this condition, both parties respect each other's profession and professional ethics. PR pays attention to the professional ethics of public relations in carrying out media relations activities. It is related to providing data and information, best services and maintaining relationships with journalists in a professional manner. It must be well connected in unity with the fundamental corridors. Journalist observations PR as a source of information for press. Journalists will appreciate good credibility of PR due to trusted and relied information. Both PR and Journalists have professional ethics.

PR appreciates journalists as equal partners. They need to maintain good relations with journalists and the media through several activities. In addition, journalists provide information to each other correctly and precisely. PR ethics is shown on PR treatment and respect their partners in unity with the existing code. The interpretations of some PR in giving envelopes or jale are considered as unrespected attitude toward the journalist profession.

The giving of envelopes or popularly known as "jale" in press events becomes dilemma because the corridor is very gray. The journalist's professional ethics prohibits receiving gifts in the press event. Envelopes or jale is still occured in several events and there are some journalists who actually ask for it. They are known as bodrek journalists. In the other hand, Journalists from credible media is strictly forbidden to receive envelopes or jale on duty. Goody bag can still be accepted by journalists with reasonable content due to the theme of activity. Reporting news is the responsibility of journalists. The media prohibits journalists from receiving envelopes or money. The gift items are still allowed. Journalists do not expect an envelope in their duties as journalists and this will hurt their profession. PR must understand the position and ethics of the journalist profession. So, there is no envelope to the journalist. Media prohibits its journalists received an envelope on duty. There are sanctions for bad journalist. 


\section{Conclusion}

Some public relations professions are occupied by educational backgrounds rather than communication with public relations conferences. Thus, the knowledge of some public relations practitioners with different levels of education makes less understanding of public relations ethics and the value of balanced partnerships with the media. There is an assumption about press event without envelopes. The media will less in participant and the publication will be minimal. Commonly, reporters who ask for regular envelopes come from unknown media. The culture is background of giving envelope or Jale. There are some organizations that allow their worker to get an envelope as common and necessary stuffs.

\section{References}

[1]. Journalistic Code of Ethics 2008 (rnalistic Code of Ethics determined by Press Council through Press Council Regulation Number: 6/Regulation-DP/V/ 2008 about Ratification of Press Council Decree Number 03/SK-DP/III/2006 about Journalistic Code of Ethics as Press Council Regulation)

[2]. IPRA 2011 Code of https://www.ipra.org/static/media/uploads/code_of_conduct/indonesian.pdf

[3]. P. Baines, J. Egan, W. Jefkins, Public Relations: Contempory issues and techniques. Boston: Elsevier/Butterworth-Heineman, 2004

[4]. S. J. Baran, Introduction to Mass Communication: Media Literacy and Culture. McGraw-Hill, 2004.

[5]. G. M. Brom, Effective Public Relations. N.J. : Pearson Prentice Hall, 2009

[6]. C. L. Bovee, J. V. Thill, Excellence in Business Communication. Addison Wesley Publishing Company Incorporated, 2006.

[7]. S. Baker, D. L. Martinson, The TARES Test: Five Principles for Ethical Persuasion. Journal of Mass Media Ethics, 16(2\&3), pp 148-175, 2002.

[8]. B. Kovach, T. Rosenstiel, The Element of Journalism: What Newspeople Should Know and the Public Should Expect. Three Rivers Press, 2014.

[9]. N. K. Denzin, Y. S. Lincoln, The Sage Handbook of Qualitative Reseach. California: Sage Publication, 2005.

[10]. R. K. Yin, Case Study Reseach Design and Methods. California: Sage Publications., 2013. 